\title{
Relationships between Oil Price and Stock Market: An Empirical Analysis from Istanbul Stock Exchange (ISE)
}

\author{
Assist. Prof. Dr. Ayhan Kapusuzoglu \\ Department of Banking and Finance, Faculty of Management \\ Yildirim Beyazit University, Ankara, TURKEY \\ Tel: 90-312-324-1555 E-mail: ayhkap@gmail.com
}

Received: July 5, 2011

Accepted: August 22, 2011

Published: November 1, 2011

doi:10.5539/ijef.v3n6p99

URL: http://dx.doi.org/10.5539/ ijef.v3n6p99

\begin{abstract}
The present study examined long-term relationships and short-term dynamics between National 100, National 50 and National 30 Index of Istanbul Stock Exchange (ISE) and international Brent oil price by using various econometric techniques. The study, in which relationships of three index with oil price are sought separately, encompasses the period between 04.01.2000 and 04.01.2010 and was performed with data consisting of 2437 days. As a result of applied Johansen cointegration test, it was determined that there was a cointegrated relationship between each index and oil price, with other words, there was a long term relationship between each of the three index and oil price. As a result of Granger causality analysis, it was observed that there was one way causality relationship from all index of the stock exchange market to oil price, but oil price was not the causal of each of the three index.
\end{abstract}

Keywords: Stock price, Oil price, Cointegration, Causality, ISE

JEL Classification: C12, C58, G12

\section{Introduction}

Oil has a great importance in the current world economy. The widespread use of it has increased dependency on this product within the supply-demand equilibrium and as a result of this condition oil has gained a strategic position apart from other energy resources in the world. Producer and consumer countries quickly realized the strategic importance of oil and economic development and growth process in the world have become dependent on the oil. An increase in the price of the oil will affect the cash flow as it is an important input used in production of many goods and services, like capital and work force, according to Gisser and Goodwin (1986) in their attempt to explain the relationship between oil price and stock prices. Increasing oil prices will increase the production costs under the circumstances where there is no substitution possibility between factors of production, higher production costs will affect cash flow and will decrease stock prices. At the same time, increasing oil prices will affect the reduction ratio within the asset pricing model. Due to the inflationist pressure created by increasing oil prices, central bank might increase interest rates in order to control the inflation. More interest rates will lead to the preference of treasury bills and bonds against stocks. This preference shift will lead to decrease in stock prices. Total effect of increasing oil prices on stock prices will vary depending on the fact whether firm is consumer or producer of oil or oil products (Iscan, 2010).

There are numerous researches having different findings in the field literature that consider the relationship between oil prices and stock returns. In his study, Sadorsky (1999) examined the relationship between shocks that occurred in oil prices in U.S.A and the stock exchange. As a result of the study performed in the period between 1947-1996, in which VAR and GARCH analyzes were applied and interest rate and industrial production output were included, it was revealed that oil prices and volatility in the oil prices play essential role in affecting the returns of stocks and shock volatilities that occurred in oil prices have asymmetric effect on the economy. Papapetrau (2001) in his study investigated the dynamic relationship between oil price shocks, stock exchange (stock prices) and economic activities (interest rate, work force) in Greece. As a result of the research study performed in the period between 1989-1999 and where VAR analysis was applied, it was determined that the changes in the oil prices affect the real economic activities and are important factors in studying the stock exchange price movements of oil price.

In his study Maghyereh (2004) looked into the interaction between shocks that occurred in oil prices and stock markets of relevant countries. According to the results of the study, it was found that shocks that occured in oil 
prices did not have meaningful effect on stock index returns of developing countries. Sari and Soytas (2006) examined the relationship between crude oil price, stock return, interest rate and output within the period 1987-2004 in the scope of Istanbul Stock Exchange (ISE). According to the results of the research, shocks that occurred in oil prices did not have meaningful effect on stock returns. In their studies Anoruo and Mustafa (2007) looked into the relationship between oil and stock market returns in the period 1993-2006 in U.S.A. According to the result of the study, in which cointegration test and VECM model were used, it was revealed that there was a long term relationship (cointegration) between stock market and oil market and there was a one way causality relationship from stock market returns to oil market returns.

Park and Ratti (2008) looked into the effect of the shocks that occurred in oil prices on stock exchange returns in the scope of U.S.A. and 13 European countries. In the study performed for the period 1986-2005 and in which VAR model was used, it was determined that price shocks that occurred in general basis had effect on stock exchange returns, oil price increase in Norway also increased stock exchange returns and increase in volatility of oil prices in many European countries except U.S.A. had negative effect on stock exchange returns. In their research, Cong, Wei, Jiao and Fan (2008) examined the interactive relationship between shocks that occurred in oil prices and stock market in China. In the study performed in the period between 1996-2007 and where VAR model was used, it was revealed that shocks that occurred in oil prices did not have meaningful effect on stock returns and some important shocks that occurred, negatively affected the stocks of oil companies.

Miller and Ratti (2009) investigated the long term relationship between world crude oil prices and international stock exchanges. According to the results of the study performed within period of 1971-2008 (seperated based on periods) in the scope of OECD countries and in which VECM model was used, it was observed that there had been a long term relationship between variables between periods 1971-1980 and 1988-1999 and the stock exchange had responded negatively to the increase in oil prices in the long term. In his study Oberndorfer (2009) looked into the relationship between developments that had occurred in energy markets in Euro zone and prices of energy stocks in Europe. In the research performed for the period 2002-2007 and in which ARCH and GARCH analyzes were applied, it was revealed that increases in oil prices negatively affected European stock returns, and volatilities in coal prices affected stock returns, but did not have a big impact as much as oil price, and the natural gas had no effect on the prices of energy stocks.

Arouri, Lahiani and Bellalah (2010) examined the relationship between shocks that had occurred in oil prices and stock returns by using linear and non-linear models within the period of 2005-2008 among countries exporting oil. According to the results of the research, it was revealed that stock returns in Qatar, Oman, Saudi Arabia and United Arab Emirates had responded to changes in oil prices, though change that had occurred in oil prices in Bahrain and Kuwait did not affect the stock returns. In his study performed in the scope of Greece, Filis (2010) looked into the relationship between macroeconomic factors (customer price index and industrial production), stock exchange and oil prices. In the study performed between periods 1996-2008 and in which VAR model is applied, it was determined that long term oil prices and stock exchange index had positive effect on customer price index, oil prices had negative effect on stock exchange and oil prices did not have any effects on industrial production. In the same way, no relationship was found between stock exchange and industrial production.

Also in the present study, cointegration and causality tests have been applied by using daily closing values of ISE National 100, National 50 and National 30 Index between years 2000-2010 and international Brent oil price in order to test the causality relationship between stock market in Turkey and international oil prices. It has been considered that the long time period which constitutes the scope of the study and seperate consideration of the relationships between three fundamental index and international oil price distinguish the study from other studies in the literature and would make an important contribution to the field literature.

\section{Metholodogy}

\section{1..Data Set}

Data set used in this study encompasses the period 04.01.2000-04.01.2010 and analyses have been performed by using 2437 data on daily basis. Closing data pertaining to ISE National 100, National 50 and National 30 Index have been obtained from Republic of Turkey Central Bank Electronic Data Distribution System (http://www.imkb.gov.tr), and international Brent oil price data (\$) have been obtained from U.S. Energy Information Administration Data Distribution System (http://www.eia.doe.gov). For time values of oil prices, especially Brent oil prices per barrel, validity of which is high among international markets has been preferred. Microsoft Office Excel 2007 and Eviews 6.0 package program have been used for arranging the data and implementation of econometric analyses.

\subsection{Methods}

Firstly, natural logarithms of data have been taken before passing to the analysis process. Then, stationarity analysis has been performed for data pertaining to the variables used in the study. The most widely used tests among 
parametric tests are Augmented Dickey-Fuller (ADF-1979) and Philips-Perron (PP-1988) tests that considers possible structural fracture and trend in the time series. At the same time, Kwiatkowski-Phillips-Schmidt-Shin (KPSS-1992) test was performed for supporting the results obtained. A long term relationship between time series has been searched by applying cointegration test developed by Johansen and Juselius (1990). Finally, the direction of the relationship between variables has been examined with Granger causality test.

\subsubsection{Unit root test}

It is necessary to look into the case, whether time series are stationary before making analysis with time series data. Stationarity analysis is also called unit root test. A series, which does not have unit root problem, is regarded as a stationary series. In case of considering unstationary time series, there is a possibility of encountering with fake regression problem. In this case, the result obtained by regression analysis will not reflect the real relationship (Gujarati, 1999). Certain problems arise in models formed by using unstationary time series and a relationship that does not exist between variables is interpreted wrongly, and assessed as if it exists. Various parametric and non-parametric tests have been developed for finding whether a series is stationary or not or includes unit root. The fact whether time series used in this model have unit roots or not, have been investigated by using Augmented Dickey-Fuller (ADF-1979) and Phillips-Perron (PP-1988) test methods. It is decided upon rejection or acceptance of the $\mathrm{H}_{0}$ hypothesis by comparing the statistics obtained by the test with critical value (Enders, 1995). $\mathrm{H}_{0}$ hypothesis shows that series is not stationary and has unit root, alternative hypothesis shows that series is stationary. If the calculated value is bigger than the absolute critical value, then $\mathrm{H}_{0}$ hypothesis is rejected and series is decided to be stationary.

$\mathrm{H}_{0}$ : Series is not stationary (there is unit root)

$\mathrm{H}_{1}$ : Series is stationary (there is no unit root)

The equations used in $\mathrm{ADF}(1)$ and $\mathrm{PP}(2)$ tests are given as follows:

$$
\begin{array}{r}
\Delta Y_{t}=\beta_{0}+\beta_{1} t+\delta Y_{t-1}+\sum_{i=1}^{m} \beta_{i} \Delta Y_{t-i}+u_{t} \\
\Delta Y_{t}=\alpha_{o}+\alpha_{1}(t-T / 2)+\alpha_{2} Y_{t-1} \sum_{i=1}^{m} \Delta Y_{t-i}+\varepsilon_{t}
\end{array}
$$

Among the variables in the equations $\Delta \mathrm{Y}_{\mathrm{t}}=\mathrm{Y}_{\mathrm{t}}-\mathrm{Y}_{(\mathrm{t}-1)}$; $\mathrm{t}$ is the trend variable, stochastic error terms and $\mathrm{T}$ coefficient is the total number of observations.

Excess sensitivity of the results obtained from ADF and PP tests to the lag length determined has been criticized time to time. In this context, it is observed that Kwiatkowski-Phillips-Schmidt-Shin (KPSS-1992) stationarity test, which is not sensitive to lag length, is preferred in recent studies. In KPSS unit root test is calculated from two aspects being constant and constant-trend rather than three aspects as constant, constant-trend and none in ADF and PP tests. Null hypothesis of KPSS stationarity test is the reverse of the null hypothesis of ADF and PP unit root tests (Basar and Temurlenk, 2007). Thus, hypothesis to be build for KPSS test means that null hypothesis time series is stationary and on the other hand alternative hypothesis means that time series is not stationary (Sevuktekin and Nargelecekenler, 2005). Accordingly, KPSS tests have been implemented in addition to ADF and PP tests.

\subsubsection{Johansen cointegration test}

Cointegration method has been developed by Granger as a new method in research of long term equilibrium relationships between variables. Then, this theory has been further developed with joint study made by Engle-Granger and relationships between long term equilibrium relationships and short term dynamic relationships. It became possible to reveal whether unstationary series in the level act together in the long term, thanks to Engel-Granger cointegration test developed by Engle and Granger and Johansen cointegration test developed by Johansen and Juselius (1990). Hypothesis to be examined with Johansen cointegration test to be applied on the study has been presented below:

$\mathrm{H}_{0}$ : There is no cointegration relationship between variables

$\mathrm{H}_{1}$ : There is cointegration relationship between variables

2.2.3. Vector error correction model (VECM)

In case of determination of cointegration relationship (cointegration vector) that shows the presence of long term relationship between variables, causality relationships must be analyzed with error correction model (Vector Error 
Correction Model, VECM). In this direction, VECM was applied in the study and equations regarding the model have been presented below:

$$
\begin{aligned}
& \Delta X_{t}=\alpha_{0}+\sum_{i=1}^{a} \alpha_{i} \Delta Y_{t-i}+\sum_{i=1}^{b} \beta_{i} \Delta X_{t-i}+\lambda E C_{t-1}+u_{x t} \\
& a Y_{t}=\beta_{0}+\sum_{i=1}^{a} \alpha_{i} \Delta Y_{t-i}+\sum_{i=1}^{b} \beta_{i} \Delta X_{t-i}+\lambda E C_{t-1}+u_{y t}
\end{aligned}
$$

In the models above; $\alpha$ and $\beta$ indicate the parameters to be estimated, a and $b$ coefficients indicate lag lengths, $\mathrm{EC}_{\mathrm{t}-1}$ coefficient indicates error correction term, $\mathrm{X}$ and $\mathrm{Y}$ coefficients indicates independent or dependent variables.

\subsubsection{Granger causality test}

Moreover, Granger causality test has been performed in the study in order to determine the direction of the relationship between the variables used in the model. Granger causality test is performed in order to determine the direction of the relationship between variables (Granger, 1969). The following model has been estimated in order to determine the direction of causality:

$$
\begin{array}{r}
Y_{t}=\alpha_{0}+\sum_{i=1}^{k 1} \alpha_{i} Y_{t-i}+\sum_{i=1}^{k 2} \beta_{i} X_{t-i}+\varepsilon_{t} \\
X_{t}=\chi_{0}+\sum_{i=1}^{k 3} \chi_{i} X_{t-i}+\sum_{i=1}^{k 4} \delta_{i} Y_{t-i}+v_{t}
\end{array}
$$

In the models above, $\mathrm{k}$ shows the lag length and it is assumed that error terms are independent from each other (white noise) (Granger 1969). If all of the coefficients in the equation numbered (5) are meaningless as a whole, and coefficients in the equation numbered (6) are meaningful as a whole, then there is a one way causality from Y (independent variable) to $\mathrm{X}$ (dependent variable). $\mathrm{Y}$ is Granger causal of $\mathrm{X}$. If causality relationship has one way direction like above, this condition might mean that $\mathrm{Y}$ and $\mathrm{X}$ from variables in the model are external and internal variables, respectively (Grene, 2008).

\section{Empirical results}

\subsection{Descriptive statistics results}

Basic statistical values of the data were calculated in the first phase regarding the data examined in the study and are shown in Table 1. When descriptive statistics shown in Table 1 related to the variables considered in the scope of the analysis are examined, the average values of variables were found to be oil price (3.779), ISE 100 (10.000), ISE $50(9,990)$ and ISE $30(10.233)$, standard deviation values are found to be oil price (0.494), ISE $100(0.592)$, ISE 50 (0.596) and ISE 30 (0.592). When average values of the variables are considered in terms of the case that data do not have normal distribution, it can be said that variables are not distributed normally in full, but are distributed very close to normal distribution as the median values of variables are very close to average values.

Regarding whether series are distributed normally or not; skewness, kurtosis and Jarque-Bera statistics were considered. If kurtosis value of relevant variables is bigger than 3 , it indicates that series is sharp, if it is smaller than 3 , it indicates that series is oblate. In consideration of skewness values, if skewness value is equal to zero, it indicates that series has normal distribution, if the skewness value is bigger than zero; it means that series is skew in the positive direction, if skewness value is smaller than zero; it indicates that series is skew in negative direction. Following values were found: skewness value of oil price variable (0.252), kurtosis value (2.007), Jarque-Bera value (125.901); skewness value of ISE 100 variable (-0.083), kurtosis value (1.569), Jarque-Bera value (210.528); skewness value of ISE 50 variable (-0.090), kurtosis value (1.568), Jarque-Bera value (211.337) and skewness value of ISE 30 variable (-0.098), kurtosis value (1.568), Jarque-Bera value (212.066). According to these calculated values; it has been found that oil price variable is skew (inclined) and oblate in the positive direction, ISE 100 variable is skew (inclined) and oblate in negative direction, ISE 50 variable is skew (inclined) and oblate in negative direction and ISE 30 is skew (inclined) and oblate in negative direction.

\subsection{Unit root test results}

With purpose of examining the stationarity of the data, unit root test was applied. In the first phase, it was examined whether variables are stationary in the level I(0). Accordingly, ADF and PP tests were performed in terms of 2 seperate models being with constant and constant-trend. PP test is a test that is applied in supporting of ADF test. With purpose of seeing the reliability of the results obtained from ADF and PP tests, KPSS test was performed in 
terms of 2 seperate models being with constant and constant-trend. Lag numbers applied in performance of ADF unit root test are lag values determined according to Schwarz Information Criterion (SIC). In PP test, dependent variable is not included into lag model so that it will be sufficient to eliminate auto-correlation, instead Newey-West method was used. In the same way, Newey-West method was used in determination of lag numbers in KPSS test.

Results of unit root test applied in the levels for variables were presented in Table 2. When Table 2 is examined, it has been observed that all variables are not stationary in both 2 separate models (constant and constant-trend) in ADF, PP and KPSS tests and they have unit roots. If both variables are not stationary after unit root tests performed in their levels, relevant variables are made stationary by taking their differences. Accordingly, I(1) ADF, PP and KPSS unit root tests were performed again by taking the first differences in order to make the variables stationary and results are shown in Table 3 .

When results of ADF, PP and KPSS unit root test are examined after their performance by taking the differences of series from first degree, it is observed that all variables are not $\mathrm{I}(0)$ stationary in their levels and they become stationary when their first degree differences I(1) are taken. Findings found by ADF unit root test are also supported by the results of PP test. Findings obtained from KPSS test are consistent with results of ADF and PP test. According to these results, as all variables are integrated from the first degree I(1), it is concluded that there can be a cointegrated relationship between variables. Therefore, it will be possible to look into the matter, whether there is a long term relationship (cointegration) between oil price variable and ISE 100, ISE 50 and ISE 30 variables.

\subsection{Johansen cointegration test results}

Results of Johansen cointegration test applied with purpose of finding whether there is a long term relationship between oil price and ISE 100, ISE 50 and ISE 30 variables within the scope of the analysis, are shown in Table 4 and 5. The lag number to be taken into account in application of cointegration test for each comparison was calculated according to Schwarz (SIC), Akaike (AIC) and Hannan-Quinn (HQ) information criterion as 1 (one) and was included in to the model.

Results of Johansen cointegration test applied with relation to three seperate comparison models are shown in Table 4 and 5. Eigenvalues found with Johansen cointegration test are as follows: $(\lambda 1)=0.029,(\lambda 2)=0.019,(\lambda 3)=0.009$, $(\lambda 4)=0.008,(\lambda 5)=0.003$ and $(\lambda 6)=0.002$. When eigenvalue results pertaining to variables (Table 4$)$ are examined in terms of trace statistics, it was observed that Johansen trace statistics values $(28.079,27.499$ and 26.998) in three models are bigger than critical value (19.937) in the statistical significance level of $1 \%$ and there is one cointegration vector (cointegration relationship). In this way the hypothesis asserting that there is no cointegration relationship can be rejected.

When eigenvalue results pertaining to variables (Table 5) are examined in terms of maximum eigenvalue statistics, it was observed that Johansen maximum eigenvalue statistics values $(27.525,26.945$ and 26.116$)$ in three models are bigger than critical value (18.520) in the statistical significance level of $1 \%$ and there is one cointegration vector (cointegration relationship). As same as in the result of the trace statistics value, nullity hypothesis mentioning that there is no cointegration relationship can be rejected for each of three models as a result of maximum value statistics. Consequently, both trace and maximum value (eigen) values show that there is a long term relationship (cointegration) between relevant variables, in other words there is a long term relationship between ISE 100, ISE 50 and ISE 30 index and international oil price.

\subsection{Granger causality test results}

Results of Granger Causality-Block Exogeneity Wald test performed based on Vector Error Correction Model (VECM) with purpose of revealing whether there is a causality relationship between variables in each model, are shown in Table 6. If to look at Table 6, one will observe that ISE $100(\chi 2=4.376, \mathrm{p}=0.036)$, ISE $50\left(\chi_{2}=4.277\right.$, $\mathrm{p}=0.038)$ and ISE $30\left(\chi^{2}=3.877, \mathrm{p}=0.048\right)$ index are Granger cause in the $5 \%$ significance level of international oil price, and international oil price is not a Granger cause of any index. According to the obtained results, it can be said that ISE 100, ISE 50 and ISE 30 index have one way causality relationship in the direction of international oil price.

\section{Conclusion}

In this study, long term relationship and causality relationship between ISE National 100, National 50 and National 30 Index of Istanbul Stock Exchange (ISE) and international Brent oil price were examined by using econometric techniques in the scope of the period 2000-2010. As a result of analyses made, a long term relationship between all stock market index and international oil price in the period of examination, in other words, it has been observed that each stock index is cointegrated with international oil price. This obtained result can be interpreted as relevant variables act together in the long term. When results obtained from Granger causality analysis are considered, it has been revealed that each stock index has one way causality relationship towards international oil price, and 
international oil price is not a causal of any index. Findings obtained from cointegration analysis show are line with results obtained from the studies of Anoruo and Mustafa (2007) and Miller and Ratti (2009), and findings obtained from Granger causality analysis are in line with results obtained by Maghyereh (2004), Sari and Soytas (2006), Anoruo and Mustafa (2007). When obtained results are considered, it can be said that stock exchange returns in Turkey are signalling change in rational crude oil prices.

\section{References}

Anoruo, E., Mustafa, M. (2007). An empirical investigation into the relation of oil to stock markets prices. North American Journal of Finance and Banking Research, 1 (1), 22-36.

Arouri, M. H. E., Lahiani, A., \& Bellalah, M. (2010). Oil price shocks and stock market returns in oil-exporting countries: The case of GCC countries. International Journal of Economics and Finance, 2(5), pp. 132-139.

Basar, S., Temurlenk, M. S. (2007). Çevreye uyarlanmış Kuznets eğrisi: Türkiye üzerine bir uygulama. Atatürk Üniversitesi İktisadi ve İdari Bilimler Fakültesi Dergisi, 21 (1), pp. 1-12.

Cong, R-G., Wei, Y-M., Jiao, J-L., \& Fan, Y. (2008). Relationships between oil price shocks and stock market: An empirical analysis from China. Energy Policy, 36, pp. 3544-3553. http://dx.doi.org/10.1016/j.enpol.2008.06.006

Dickey, D., Fuller, W. (1979). Distribution of the estimators for autoregressive time series with a unit root. Journal of the American Statistical Association, 74 (366), pp. 427-431.

Enders, W. (1995). Applied econometric time series. New York: John Wiley \& Sons, Inc.

Filis, G. (2010). Macro economy, stock market and oil prices: Do meaningful relationships exist among their cyclical fluctuations? Energy Economics, 32, pp. 877-886. http://dx.doi.org/10.1016/j.eneco.2010.03.010

Gisser, M., Goodwin, T. H. (1986). Crude oil and the macroeconomy: Tests of some popular notions: Note. Journal of Money, Credit and Banking, 18 (1), pp. 95-103. http://dx.doi.org/10.2307/1992323

Granger, C. W. J. (1969). Investigating causal relations by econometric models and cross-spectral methods. Econometrica, 37 (3), pp. 424-438. http://dx.doi.org/10.2307/1912791

Grene, W. H. (2008). Econometric analysis. 6th Edition. New Jersey: Prentice Hall, Inc.

Gujarati, D. N. (1999). Temel ekonometri. (Çev. U. Senesen, G.G. Senesen). Istanbul: Literatür Yayınları.

Iscan, E. (2010). Petrol fiyatının hisse senedi piyasası üzerindeki etkisi. Maliye Dergisi, 158, pp. 607-617.

Johansen, S., Juselius, K. (1990). Maximum likelihood estimation and inferences on co-integration with application to the demand for Money. Oxford Bulletin of Economics and Statistics, 52 (2), pp. 169-210. http://dx.doi.org/10.1111/j.1468-0084.1990.mp52002003.x

Kwiatkowski, D., Phillips, P. C. B., Schmidt, P., \& Shin, Y. (1992). Testing the null hypothesis of stationarity against the alternative of a unit root, how sure are we that economic time series have a unit root? Journal of Econometrics, 54, pp. 159-178. http://dx.doi.org/10.1016/0304-4076(92)90104-Y

MacKinnon, J. G. (1996). Numerical distribution functions for unit root and cointegration tests. Journal of Applied Econometrics, 11 (6), pp. 601-618.

MacKinnon, J. G., Haug, A. A., \& Michelis, L. (1999). Numerical distribution functions of likelihood ratio tests for cointegration. Journal of Applied Econometrics, $14 \quad$ (5), $\quad$ pp. 563-577. http://dx.doi.org/10.1002/(SICI)1099-1255(199909/10)14:5<563::AID-JAE530>3.0.CO;2-R

Maghyereh, A. (2004). Oil price shocks and emerging stock markets: A generalized VAR approach. International Journal of Applied Econometrics and Quantitative Studies, 1-2, pp. 27-40.

Miller, J. I., Ratti, R. A. (2009). Crude oil and stock markets: Stability, instability and bubbles. Energy Economics, 31, pp. 559-568. http://dx.doi.org/10.1016/j.eneco.2009.01.009

Oberndorfer, U. (2009). Energy prices, volatility and the stock market: Evidence from the Eurozone. Energy Policy, 37, pp. 5787-5795. http://dx.doi.org/10.1016/j.enpol.2009.08.043

Papapetrou, E. (2001). Oil price shocks, stock market, economic activity and employment in Greece, Energy Economics, 23, pp. 511-532. http://dx.doi.org/10.1016/S0140-9883(01)00078-0

Park, J., Ratti, R. A. (2008). Oil price shocks and stock markets in the U.S. and 13 European countries. Energy Economics, 30, pp. 2587-2608. http://dx.doi.org/10.1016/j.eneco.2008.04.003

Phillips, P. C. B., Perron, P. (1988). Testing for unit root in the time series regression. Biometrika, 75 (2), pp. $335-346$. 
Sadorsky, P. (1999). Oil price shocks and stock market activity. Energy Economics, 21, pp. 449-469. http://dx.doi.org/10.1016/S0140-9883(99)00020-1

Sari, R., Soytas, U. (2006). The relationship between stock returns, crude oil prices, interest rates and output: Evidence from a developing economy. The Empirical Economics Letters, 5 (4), pp. 205-220.

Sevuktekin, M., Nargelecekenler, M. (2005). Zaman serisi analizi. İzmir: Nobel Yayın Dağıtım.

Table 1. Descriptive Statistics Results

\begin{tabular}{ccccc}
\hline Statistics / Variables & Oil Price & ISE 100 & ISE 50 & ISE 30 \\
\hline Mean & 3.779 & 10.000 & 9.990 & 10.061 \\
Median & 3.764 & 10.064 & 10.979 & 10.309 \\
Maximum & 4.969 & 10.972 & 8.859 & 11.219 \\
Minimum & 2.803 & 8.876 & 0.596 & 9.113 \\
Std. Dev. & 0.494 & 0.592 & -0.090 & 0.592 \\
Skewness & 0.252 & -0.083 & 1.568 & -0.098 \\
Kurtosis & 2.007 & 1.569 & 211.337 & 1.568 \\
Jarque-Bera & 125.901 & 210.528 & 0.000 & 212.066 \\
Probability & 0.000 & 0.000 & 2437 & 0.000 \\
Observations & 2437 & 2437 & & 2437 \\
\hline
\end{tabular}

Table 2. Results of ADF, PP and KPSS Unit Root Tests (Levels)

\begin{tabular}{|c|c|c|c|c|c|c|}
\hline & \multicolumn{2}{|c|}{ ADF } & \multicolumn{2}{|c|}{ PP } & \multicolumn{2}{|c|}{ KPSS } \\
\hline & Constant & $\begin{array}{c}\text { Constant and } \\
\text { Trend } \\
\end{array}$ & Constant & $\begin{array}{c}\text { Constant and } \\
\text { Trend }\end{array}$ & Constant & $\begin{array}{c}\text { Constant and } \\
\text { Trend }\end{array}$ \\
\hline Oil Price & $\begin{array}{c}-1.296[0] \\
(0.633)\end{array}$ & $\begin{array}{c}-2.461[0] \\
(0.347)\end{array}$ & $\begin{array}{c}-1.314[6] \\
(0.624)\end{array}$ & $\begin{array}{c}-2.516[4] \\
(0.319)\end{array}$ & 4.949 (a) [40] & 0.391 (a) [40] \\
\hline ISE 100 & $\begin{array}{c}-0.597[0] \\
(0.868)\end{array}$ & $\begin{array}{c}-2.594[0] \\
(0.283)\end{array}$ & $\begin{array}{c}-0.572[8] \\
(0.874)\end{array}$ & $\begin{array}{c}-2.579[7] \\
(0.289)\end{array}$ & 5.012 (a) [40] & 0.565 (a) [40] \\
\hline ISE 50 & $\begin{array}{c}-0.612[0] \\
(0.865)\end{array}$ & $\begin{array}{c}-2.635[0] \\
(0.264)\end{array}$ & $\begin{array}{c}-0.589[10] \\
(0.870)\end{array}$ & $\begin{array}{c}-2.608[9] \\
(0.276)\end{array}$ & 5.017 (a) [40] & 0.568 (a) [40] \\
\hline ISE 30 & $\begin{array}{c}-0.657[0] \\
(0.855)\end{array}$ & $\begin{array}{c}-2.695[0] \\
(0.238)\end{array}$ & $\begin{array}{c}-0.630[13] \\
(0.861)\end{array}$ & $\begin{array}{c}-2.672[12] \\
(0.248)\end{array}$ & 5.020 (a) [40] & 0.567 (a) [40] \\
\hline
\end{tabular}

Notes: () MacKinnon (1996) one-sided p-values; (a) KPSS (1992) Table-1 p-values; [ ] Lag lengths for ADF, PP and KPSS.

Table 3. Results of ADF, PP and KPSS Unit Root Tests (First Differences)

\begin{tabular}{|c|c|c|c|c|c|c|}
\hline & \multicolumn{2}{|c|}{ ADF } & \multicolumn{2}{|c|}{$\mathbf{P P}$} & \multicolumn{2}{|c|}{ KPSS } \\
\hline & Constant & $\begin{array}{c}\text { Constant and } \\
\text { Trend } \\
\end{array}$ & Constant & $\begin{array}{c}\text { Constant and } \\
\text { Trend } \\
\end{array}$ & Constant & $\begin{array}{c}\text { Constant and } \\
\text { Trend } \\
\end{array}$ \\
\hline \multirow{2}{*}{ Oil Price } & $-48.499 * * *[0]$ & $-48.489 * * *$ & $-48.495^{* * *}$ & $-48.485^{* * *}$ & $0.043^{* * *}$ (a) & $0.043^{* * *}(a)$ \\
\hline & $(0.0001)$ & {$[0](0.000)$} & [8] (0.0001) & [8] (0.000) & [7] & [7] \\
\hline \multirow{2}{*}{ ISE 100} & $-48.568 * * *$ & $-48.572 * * *$ & $-48.566 * * *$ & $-48.571 * * *$ & $0.149 * * *$ (a) & $0.097 * * *(a)$ \\
\hline & [0] (0.0001) & [0] 0.000 & [9] (0.0001) & [9] $(0.000)$ & {$[8]$} & [9] \\
\hline \multirow{2}{*}{ ISE 50} & $-48.644 * * *$ & $-48.648 * * *$ & $-48.643 * * *$ & $-48.648 * * *$ & $0.148^{* * *}(\mathrm{a})$ & $0.097^{* * *}(\mathrm{a})$ \\
\hline & [0] (0.0001) & {$[0](0.000)$} & [11] (0.0001) & [11] $(0.000)$ & {$[11]$} & {$[11]$} \\
\hline \multirow{2}{*}{ ISE 30} & $-48.735^{* * *}$ & $-48.738 * * *$ & $-48.738 * * *$ & $-48.743 * * *$ & $0.141^{* * *}(\mathrm{a})$ & $0.092 * * *(a)$ \\
\hline & {$[0](0.0001)$} & {$[0](0.000)$} & {$[14](0.0001)$} & {$[14](0.000)$} & {$[14]$} & [14] \\
\hline
\end{tabular}

Notes: *** represent the statistical significance level of 1\%; () MacKinnon (1996) one-sided p-values; $\quad$ (a) KPSS (1992) Table-1 p-values; [ ] Lag lengths for ADF, PP and KPSS. 
Table 4. Results of Cointegration Test (Trace Statistics)

\begin{tabular}{|c|c|c|c|c|c|c|c|}
\hline Models & $\mathbf{H}_{0}$ & $\mathbf{H}_{\mathbf{n}}$ & $\begin{array}{l}\text { Eigen } \\
\text { Value }\end{array}$ & $\begin{array}{c}\text { Trace } \\
\text { Statistics }\end{array}$ & $\begin{array}{c}1 \% \text { Critical } \\
\text { Value }\end{array}$ & $\begin{array}{l}5 \% \text { Critical } \\
\text { Value }\end{array}$ & $\begin{array}{c}10 \% \\
\text { Critical } \\
\text { Value }\end{array}$ \\
\hline \multirow{2}{*}{ Oil Price-ISE 100 [1] } & $\mathrm{r}=0$ & $\mathrm{r}=1$ & $0.011\left(\lambda_{1}\right)$ & $\begin{array}{c}28.079 * * * \\
(0.0004)\end{array}$ & 19.937 & 15.494 & 13.428 \\
\hline & $\mathrm{r} \leq 1$ & $\mathrm{r}=2$ & $0.0002\left(\lambda_{2}\right)$ & $\begin{array}{c}0.553 \\
(0.4568)\end{array}$ & 6.634 & 3.841 & 2.705 \\
\hline \multirow{2}{*}{ Oil Price-ISE 50 [1] } & $\mathrm{r}=0$ & $\mathrm{r}=1$ & $0.011\left(\lambda_{3}\right)$ & $\begin{array}{c}27.499 * * * \\
(0.0005)\end{array}$ & 19.937 & 15.494 & 13.428 \\
\hline & $\mathrm{r} \leq 1$ & $\mathrm{r}=2$ & $0.0002\left(\lambda_{4}\right)$ & $\begin{array}{c}0.554 \\
(0.4566)\end{array}$ & 6.634 & 3.841 & 2.705 \\
\hline \multirow{2}{*}{ Oil Price-ISE 30 [1] } & $\mathrm{r}=0$ & $\mathrm{r}=1$ & $0.010\left(\lambda_{5}\right)$ & $\begin{array}{c}26.698 * * * \\
(0.0007)\end{array}$ & 19.937 & 15.494 & 13.428 \\
\hline & $\mathrm{r} \leq 1$ & $\mathrm{r}=2$ & $0.0002\left(\lambda_{6}\right)$ & $\begin{array}{c}0.581 \\
(0.4458)\end{array}$ & 6.634 & 3.841 & 2.705 \\
\hline
\end{tabular}

Notes: *** represent the statistical significance level of 1\%; () MacKinnon-Haug-Michelis (1999) $\quad$ p-values; [ ] Lag lengths for models.

Table 5. Results of Cointegration Test (Max-Eigen Statistics)

\begin{tabular}{|c|c|c|c|c|c|c|c|}
\hline Models & $\mathbf{H}_{0}$ & $\mathbf{H}_{\mathbf{n}}$ & $\begin{array}{l}\text { Eigen } \\
\text { Value }\end{array}$ & $\begin{array}{c}\text { Max-Eigen } \\
\text { Statistics }\end{array}$ & $\begin{array}{c}1 \% \\
\text { Critical } \\
\text { Value }\end{array}$ & $\begin{array}{c}5 \% \text { Critical } \\
\text { Value }\end{array}$ & $\begin{array}{c}10 \% \\
\text { Critical } \\
\text { Value }\end{array}$ \\
\hline \multirow{2}{*}{ Oil Price-ISE 100 [1] } & $\mathrm{r}=0$ & $\mathrm{r}=1$ & 0.011 & $\begin{array}{c}27.525 * * * \\
(0.0002)\end{array}$ & 18.520 & 14.264 & 13.428 \\
\hline & $\mathrm{r} \leq 1$ & $\mathrm{r}=2$ & 0.0002 & $\begin{array}{c}0.553 \\
(0.4568)\end{array}$ & 6.634 & 3.841 & 2.705 \\
\hline \multirow{2}{*}{ Oil Price-ISE 50 [1] } & $\mathrm{r}=0$ & $\mathrm{r}=1$ & 0.011 & $\begin{array}{c}26.945^{* * *} \\
(0.0003)\end{array}$ & 18.520 & 14.264 & 13.428 \\
\hline & $\mathrm{r} \leq 1$ & $\mathrm{r}=2$ & 0.0002 & $\begin{array}{c}0.554 \\
(0.4566)\end{array}$ & 6.634 & 3.841 & 2.705 \\
\hline \multirow{2}{*}{ Oil Price-ISE 30 [1] } & $\mathrm{r}=0$ & $\mathrm{r}=1$ & 0.010 & $\begin{array}{c}26.116^{* * *} \\
(0.0004)\end{array}$ & 18.520 & 14.264 & 13.428 \\
\hline & $\mathrm{r} \leq 1$ & $\mathrm{r}=2$ & 0.0002 & $\begin{array}{c}0.581 \\
(0.4458)\end{array}$ & 6.634 & 3.841 & 2.705 \\
\hline
\end{tabular}

Table 6. VEC Granger Causality - Block Exogeneity Wald Tests Results

\begin{tabular}{cccccc}
\hline Models & Dependent & Independent & Chi-Square & Prob. & Direction \\
\hline \multirow{2}{*}{$\mathbf{1}$} & ISE 100 & Oil Price & 0.028 & 0.865 & No direction \\
& Oil Price & ISE 100 & $4.376^{* *}$ & 0.036 & Unidirection \\
\multirow{2}{*}{$\mathbf{2}$} & ISE 50 & Oil Price & 0.010 & 0.920 & No direction \\
& Oil Price & ISE 50 & $4.277^{* *}$ & 0.038 & Unidirection \\
\multirow{2}{*}{$\mathbf{3}$} & ISE 30 & Oil Price & 0.018 & 0.891 & No direction \\
& Oil Price & ISE 30 & $3.877^{* *}$ & 0.048 & Unidirection \\
\hline
\end{tabular}

Note: ** represent the statistical significance level of $5 \%$ 